\title{
Cyto-Molecular Characterization of Three Tacca Species from Bangladesh
}

\author{
Riyad Hossen, Syeda Sharmeen Sultana and Sheikh Shamimul Alam* \\ Department of Botany, University of Dhaka, Dhaka-1000, Bangladesh
}

Received January 7, 2016; accepted June 14, 2016

\begin{abstract}
Summary Three species of Tacca J. R. \& G. Forst., namely T. plantaginea, T. chantrieri and T. integrifolia, were investigated cytogenetically and at the molecular level to solve their taxonomic rank. The diploid chromosome number $2 n=28$ was found in T. plantaginea and T. integrifolia whereas $2 n=22$ was found in $T$. chantrieri. This is probably the first report on the diploid chromosome number of $T$. plantaginea and T. chantrieri around the world. The three species differed in respect of centromeric formulae such as $22 \mathrm{~m}+6 \mathrm{sm}$ in T. plantaginea, $18 \mathrm{~m}+4 \mathrm{sm}$ in T. chantrieri and $28 \mathrm{~m}$ in T. integrifolia. In addition to regular $2 n=22$ chromosomes, four to eight small chromosomes were found in some cells of $T$. chantrieri suggesting the probable occurrence of B-chromosome. In T. integrifolia, a pair of satellites was found on the short arm, one in each member of pair VI, after orcein and CMA staining but not in DAPI, revealing the GC-rich nature. A wide range of CMA- and DAPI-positive bands was found in the metaphase chromosomes of the three species. DAPIfluoresced chromosomes were frequent in these three species. Six primer combinations were applied for RAPD analysis in the three species of Tacca to find out their genomic relationship. The three species showed some unique bands useful as markers for each species. Conventional and fluorescent karyotype together with RAPD fingerprinting indicated that $T$. integrifolia is distantly related to $T$. plantaginea and $T$. chantrieri. Therefore, the compilation of the above cytological and molecular information will be very useful for authentic identification of the three Tacca species. This genetic information will help in the proper conservation of and to make patent for the three threatened Tacca species found in Bangladesh.
\end{abstract}

Key words Fluorescent banding, Karyotype, RAPD, Tacca J. R. \& G. Forst.

The genus Tacca belongs to Taccaceae. It is a small genus comprising of about 15 species mostly distributed in the tropical regions of Asia (India, Bhutan, China, Thailand, Malaysia and Indonesia) and the Pacific Islands and Australia (Borokini and Ayodele 2012, Ting and Larsen 2000, Shwe et al. 2010, Zhang et al. 2011). In Bangladesh, Tacca species are found in the hilly forest areas of the greater Sylhet and Chittagong districts and the Chittagong Hill Tracts (Ahmed et al. 2008).

The species of Tacca has tremendous medicinal importance. The rhizomes of T. chantrieri Andr. and T. plantaginea (Hance) Drenth have been used for the treatment of gastric ulcers, enteritis and hepatitis in Chinese folk medicine (Shwe et al. 2010, Chen et al. 1987, Zhou et al. 1983). A series of highly oxygenated pentacyclic steroids named taccalonolids have been isolated from T. plantaginea (Hance) Drenth. Previous phytochemical investigations revealed the presence of $(25 \mathrm{~S})$ steroid saponins, pregnane glycosides and taccalonolides in Tacca chantrieri (Yokosuka et al. 2002, 2003, 2005, Huang et al. 2002). In traditional medicine of Myanmar, the rhizomes of Tacca integrifolia Ker-Gawl. have been used for the treatment of carbuncles, skin abrasion, skin

\footnotetext{
*Corresponding author, e-mail: ssalam81@yahoo.com DOI: $10.1508 /$ cytologia.81.371
}

diseases, and various kinds of cancers (Shwe et al. 2010, Chen et al. 1987, Zhou et al. 1983, Yokosuka et al. 2002, 2003, 2005, Huang et al. 2002).

Only four Tacca species were reported from Bangladesh. These are i) Tacca plantaginea (Hance) Drenth, ii) T. chantrieri Andr., iii) T. integrifolia Ker-Gawl. and iv) T. leontopetaloides (L.) O. Kuntze. The species T. leontopetaloides was for the first time reported by Prain (1963) from the Chittagong district. However, no report about this species is available from Bangladesh after Prain (1963). According to van Steenis (1975), this species is widely distributed in the Old and New World from West Africa through South East Asia throughout Malaysia, North Australia to Polynesia. On the other hand, the other three species are restricted to the hilly areas of Greater Sylhet, Chittagong and the Chittagong Hill Tracts (Ahmed et al. 2008). Since these species are very much restricted to hilly areas, they have been used as folk medicine by different tribal peoples (Ahmed et al. 2008).

As a consequence, these plants in Bangladesh are now under severe threat. In addition, habitat destruction due to unplanned urbanization, deforestation and anthropogenic misuse of land are another threat (Ahmed et al. 2008). Therefore, scientists are paying attention to conserve this plant. Before conservation, authentic 
identification of each species is essential. Unfortunately, no measure regarding conservation and ethnobotanical exploration of these species have yet been undertaken (Ahmed et al. 2008).

In Bangladesh, the flower morphology of T. chantrieri and T. integrifolia are almost similar (flower blossoms at the top of long petiole). In contrast, the flower morphology of $T$. plantaginea (petiole very short, flower blooms just above the soil ground) is completely different from the other two species. The plant $T$. plantaginea is cited as Schizocapsa plantaginea in some other countries (Ting and Larsen 2000). Therefore, confusion about the taxonomic rank of T. plantaginea exists (Prof. Dr. Abul Hassan, Department of Botany, University of Dhaka, personal communication).

It is well known that where morphological features are meager, cytological analysis provides authentic information for identification of disputed species (Sultana and Alam 2007, Khatun and Alam 2010, Islam and Alam 2011, Khatun et al. 2011). Only a few earlier workers tried to characterize Tacca integrifolia with classical karyotype analysis, but their researches were confined to $2 n$ chromosome count $(2 n=28)$ without any karyotype information (Kumar and Subramaniam 1987, Sharma and Sarkar 1968, Baldwin and Speese 1951). On the other hand, no information about karyotype, even the diploid chromosome number for $T$. chantrieri and $T$. plantaginea, is available.

The conventional karyotype analysis alone is unable to express critically the differences among closely related species since these species usually possess similar $2 n$ chromosomes numbers and even other karyotype features (Khatun and Alam 2010, Khatun et al. 2011). Moreover, the consideration of chromosome length, arm ratio, position and number of secondary constrictions are not always sufficient to differentiate individual chromosomes. Minute deletion, inversion, tandem duplication, etc. cannot be detected by conventional karyotype analysis.

In such a case, different cytogenetical approaches should be undertaken. Staining with DNA-base specific banding with fluorochromes such as chromomycin $\mathrm{A}_{3}$ (CMA) and 4',6-diamidino-2-phenylindole (DAPI) is one of such approaches for karyotype study of related species. Fluorescent banding is quite satisfactory for detailed and critical chromosome analysis such as identification of individual chromosome, determination of the amount and site of AT- and GC-rich base pairs in chromosomes, etc. (Schweizer 1976, Alam and Kondo 1995, Kondo and Hizume 1982). Fluorescent karyotype analyses were able to solve taxonomic problems of different plant species (Jessy et al. 2005, Akter and Alam 2005, Islam and Alam 2011, Sultana et al. 2011).

Molecular markers analysis has become another important tool in studying genetic information and diversity (Bered et al. 2005). The utility of molecular markers is generally determined by the technology that is used to reveal DNA-based polymorphism. DNA fingerprinting by Random Amplified Polymorphic DNA (RAPD) is one of the molecular methods for characterizing different plant specimens. This method has been used as a versatile tool for investigating various genomic aspects of organisms. It includes characterization of genetic variability, genome fingerprinting, genome mapping, gene localization, analysis of genome evolution, population genetics, taxonomy, etc. The advantages of RAPD analysis over other methods are its low sample DNA requirement and the high frequency of polymorphic bands detected (Williams et al. 1990).

Therefore, in the present study, a combination of cytogenetical and molecular analyses has been carried out for the first time to characterize the three Tacca species found in Bangladesh.

\section{Materials and methods}

Three species of Tacca J. R. \& G. Forst. namely $T$. plantaginea, T. chantrieri and T. integrifolia (Figs. 1-3) were collected from the hilly forest of Rama Kalayaga, Hobigang, Bangladesh and maintained in the Botanical Garden, Department of Botany, University of Dhaka, Bangladesh.

\section{Cytogenetical study}

Healthy roots were collected and pretreated with 8-hydroxyquinoline $(0.002 \mathrm{M})$ for $20 \mathrm{~min}$ at $20-25^{\circ} \mathrm{C}$ followed by $15 \mathrm{~min}$ fixation in $45 \%$ acetic acid at $4^{\circ} \mathrm{C}$. The pretreated RTs were hydrolyzed for 20-40s (depending on thickness of root) at $60^{\circ} \mathrm{C}$ in a mixture of $1 \mathrm{~N} \mathrm{HCl}$ and $45 \%$ acetic acid $(2: 1)$. The root tips were stained and squashed in 1\% aceto-orcein. For CMAand DAPI banding, Alam and Kondo's (1995) method was used with slight modification. After hydrolysing and dissecting, the materials were squashed with $45 \%$ acetic acid. The cover glasses were removed quickly on dry ice and allowed to air dry for at least $24 \mathrm{~h}$ before study. The air-dried slides were first pre-incubated in McIlvaine's buffer ( $\mathrm{pH}$ 7.0) for $30 \mathrm{~min}$ followed by Distamycin A $\left(0.1 \mathrm{mg} \mathrm{mL}^{-1}\right)$ treatment for $10 \mathrm{~min}$. The slides were rinsed mildly in McIlvaine's buffer supplemented with $\mathrm{MgSO}_{4}(5 \mathrm{mM})$ for $15 \mathrm{~min}$. One drop of CMA $\left(0.1 \mathrm{mg} \mathrm{mL}^{-1}\right)$ was added to the materials for $15 \mathrm{~min}$ in a humid chamber and then rinsed with McIlvaine's buffer with $\mathrm{MgSO}_{4}$ for $10 \mathrm{~min}$. Slides were mounted in $50 \%$ glycerol and kept at $4{ }^{\circ} \mathrm{C}$ overnight before observation. These were observed under a Nikon (Eclipse 50i) fluorescent microscope with a blue violet (BV) filter cassette. For DAPI-staining, after $24 \mathrm{~h}$ of air drying, the slides were first pre-incubated in McIlvaine's buffer ( $\mathrm{pH} \mathrm{7.0)}$ for $27 \mathrm{~min}$ and treated in Actinomycin $\mathrm{D}\left(0.25 \mathrm{mg} \mathrm{mL}^{-1}\right)$ for $10 \mathrm{~min}$ in a humid chamber. The slides were immersed in a DAPI solution $\left(0.01 \mathrm{mg} \mathrm{mL}^{-1}\right)$ 

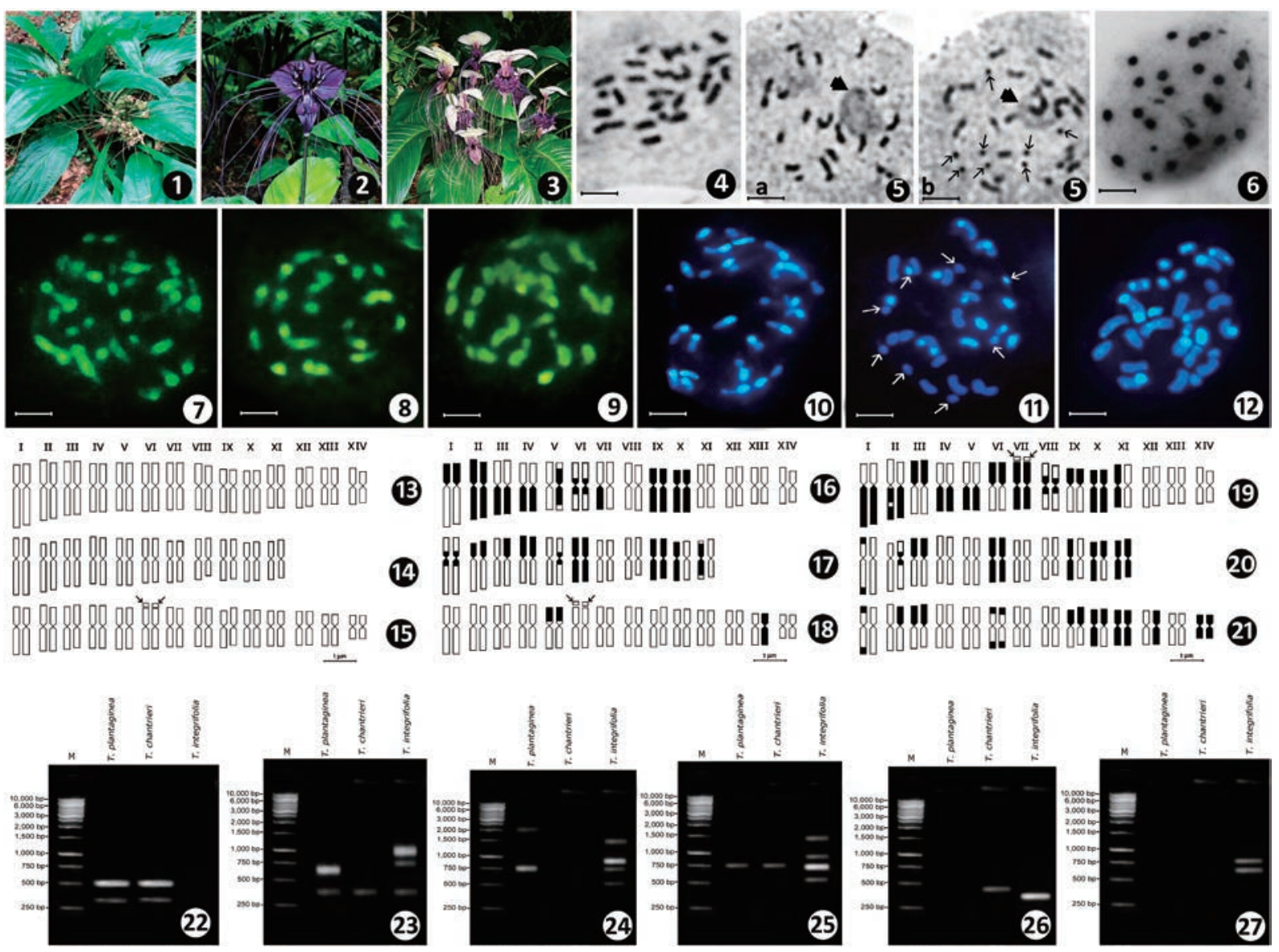

Figs. 1-27. Plant morphology, Orcein-, CMA- and DAPI-stained mitotic metaphase and RAPD analysis of three species of Tacca J. R. \& G. Forst. 1. Plant morphology of T. plantaginea, 2. Plant morphology of T. chantrieri, 3. Plant morphology of T. integrifolia, 4. Orcein-stained mitotic metaphase chromosomes of T. plantaginea, 5. Orcein-stained mitotic metaphase chromosomes of $T$. chantrieri (a. $2 n=22$, b. $2 n=22+8$ small chromosome, arrow) (nucleolus indicated by arrow head), 6. Orcein-stained mitotic metaphase chromosomes of T. integrifolia, 7. CMA-stained mitotic metaphase chromosomes of T. plantaginea, 8. CMA-stained mitotic metaphase chromosomes of T. chantrieri, 9. CMA-stained mitotic metaphase chromosomes of T. integrifolia, 10. DAPI-stained mitotic metaphase chromosomes of T. plantaginea, 11. DAPI-stained mitotic metaphase chromosomes of T. chantrieri, 12. DAPI-stained mitotic metaphase chromosomes of $T$. integrifolia, Bar $=5 \mu \mathrm{m}, 13$. Orcein-idiogram of $T$. plantaginea, 14. Orcein-idiogram of T. chantrieri, 15. Orcein-idiogram of T. integrifolia, 16. CMA-idiogram of T. plantaginea, 17. CMA-idiogram of T. chantrieri, 18. CMA-idiogram of T. integrifolia, 19. DAPI-idiogram of T. plantaginea, 20. DAPI-idiogram of $T$. chantrieri, 21. DAPI-idiogram of $T$. integrifolia, arrow indicates satellite, Bar $=1 \mu \mathrm{m}, 22$. RAPD with primer OPA-6, 23. RAPD with primer-4, 24. RAPD with primer-5, 25. RAPD with primer-7, 26. RAPD with primer-8 and 27. RAPD with primer-11.

for $20 \mathrm{~min}$ and mounted with $50 \%$ glycerol. These were observed under a Nikon (Eclipse 50i) fluorescent microscope with an ultra violet (UV) filter cassette.

\section{DNA isolation}

Leaves were harvested and total genomic DNA was extracted by using a modified CTAB method (Doyle 1987). DNA concentration was quantified through a spectrophotometer (Analylikjena, Specord 50, Germany). The A 260/280 readings for DNA samples were $1.6-1.8$.

\section{PCR amplification and primer survey}

The PCR reaction mixture $(25 \mu \mathrm{L})$ contained template DNA (25ng) $2 \mu \mathrm{L}$, de-ionized distilled water $18.8 \mu \mathrm{L}$, Taq buffer $\mathrm{A} 10 \times$ (Tris with $15 \mathrm{mM} \mathrm{MgCl}_{2}$ ) $2.5 \mu \mathrm{L}$, primer $(10 \mu \mathrm{M}) 1.0 \mu \mathrm{L}$, dNTPs $(2.5 \mathrm{mM}) 0.5 \mu \mathrm{L}$ and Taq DNA polymerase $\left(5 \mathrm{U}_{\mu} \mathrm{L}^{-1}\right) 0.2 \mu \mathrm{L}$. PCR amplification was done in an oil-free thermal cycler (Biometra UNOII, Germany) for 46 cycles after initial denature at $94^{\circ} \mathrm{C}$ for $5 \mathrm{~min}$, denature at $94^{\circ} \mathrm{C}$ for $1 \mathrm{~min}$, annealing at $34-36^{\circ} \mathrm{C}$ for $30 \mathrm{~s}$, extension at $72^{\circ} \mathrm{C}$ for $3 \mathrm{~min}$ and final extension at $72^{\circ} \mathrm{C}$ for $5 \mathrm{~min}$. Six random primers, such as OPA-6 (5'-GGT-CCC-TGA-C-3'), primer-4 (5'-GGG-TAACGC-C-3'), primer-5 (5'-TCA-CGT-CCA-C-3'), primer-7 (5'-CCC-GCC-TTC-C-3'), primer-8 (5'-GTC-CTC-GTAG-3') and primer-11 (5'-CAC-GGC-TGC-G-3'), were used in the present study for screening.

\section{Gel electrophoresis}

The amplified products were separated electrophoretically on $1 \%$ agarose gel. The gel was prepared us- 
ing $1.0 \mathrm{~g}$ agarose powder containing ethidium bromide $\left(10 \mathrm{mg} \mathrm{mL}^{-1}\right) 8 \mu \mathrm{L}$ and $100 \mathrm{~mL} 1 \times \mathrm{TAE}$ buffer. Agarose gel electrophoresis was conducted in $1 \times \mathrm{TAE}$ buffer at $50 \mathrm{~V}$ and $100 \mathrm{~mA}$ for $1.5 \mathrm{~h}$. DNA ladder $(1 \mathrm{~kb})$ was electrophoresed alongside the RAPD reactions as marker. DNA bands were observed on a UV-transilluminator and photographed by a gel documentation system.

\section{Scoring and data analysis}

The PCR products were analyzed after gel electrophoresis. The photographs were critically discussed on the basis of presence (1) or absence (0), size of bands and overall polymorphism of bands. These were carried out for further investigation. The scores obtained using all primers in the RAPD analysis were then pooled for constructing a single data matrix. This was used for estimating polymorphic loci, Nei (1972) gene diversity, genetic distance (D) and constructing a UPGMA (Unweighted Pair Group Method of Arithmetic Means) dendrogram among the specimen using the computer program "POPGENE" (Version 1.31).

\section{Results and discussion}

\section{Conventional karyotype}

Tacca plantaginea and T. integrifolia were found to possess $2 n=28$ chromosomes (Figs. 4,6 ). On the other hand, $2 n=22$ chromosomes were found in $T$. chantrieri (Fig. 5). The diploid chromosome number $2 n=28$ for $T$. integrifolia was reported earlier (Kumar and Subramaniam 1987). Therefore, the plants of T. integrifolia found in Bangladesh had a similar chromosome number to that of the previous reports (Fig. 5, Table 1).

In contrast, no reports on the diploid chromosome number of Tacca plantaginea and T. chantrieri were found in the available literature, Chromosome Atlas or internet sources. Therefore, this is probably the first report on the diploid chromosome number of T. plantaginea and T. chantrieri (Figs. 4, 6, Table 1).

The three species differed in respect of centromeric formulae such as $22 \mathrm{~m}+6 \mathrm{sm}$ in Tacca plantaginea, $18 \mathrm{~m}+4 \mathrm{sm}$ in $T$. chantrieri and $28 \mathrm{~m}$ in $T$. integrifolia (Figs. 13-15, Table 1). The results indicated that $T$. plantaginea and $T$. chantrieri have a relatively heterogeneous karyotype than $T$. integrifolia. According to Stebbins (1971), the heterogeneous karyotypes are advanced. In this regard, T. plantaginea and T. chantrieri are relatively advanced than $T$. integrifolia.

\section{B-chromosome?}

In Tacca chantrieri, in addition to the regular $2 n=22$ chromosomes, four to eight small chromosomes were found in some cells (Fig. 5b, arrows). The number of this kind of chromosome-like bodies was not fixed and varied from four to eight per cell. This body was very small, about $0.4 \mu \mathrm{m}$ in length, and thus could not be ar- ranged with the normal complements in the respective idiogram (Fig. 5b, arrows). The above features suggest that these chromosome-like bodies are "B-chromosomes". B-chromosomes were reported in different species such as Lathyrus sativus L. (Badr et al. 2009) and Datura metal L. (Alam and Begum 2001). Since there is no chromosomal information available for T. chantrieri, it was not possible to compare the presence of B-chromosomes in this species. Generally B-chromosomes are heterochromatic in nature. As a result, there is no impact of its presence or absence on the morphology of the plant. Moreover, after DAPI staining, well fluoresced small chromosome-like bodies were found in a few cells (Fig. 11, arrows). However, no such body was observed in any cell after CMA staining (Fig. 8). Therefore, the B-chromosomes of $T$. chantrieri are AT-rich heterochromatic in nature (Schweizer 1976, Alam and Begum 2001).

\section{Satellite}

In Tacca integrifolia, a pair of satellites was found on the short arm, one in each member of pair VI, after orcein and CMA staining (Figs. 15, 18). However, no satellite was found after DAPI staining. It indicated the CMA positive and DAPI negative nature of the satellite portions (Khatun and Alam 2010, Sultana and Alam 2007, Schweizer 1976, Alam and Begum 2001). Since CMA binds with GC-rich repetitive sequences, the satellited portions of T. integrifolia were completely GC-rich in nature (Schweizer 1976).

In contrast, a pair of satellite was found, one in each member of pair VII of $T$. plantaginea, after DAPI staining (Fig. 19). No satellite was found after CMA and even orcein staining (Figs. 13, 16). The reversible fluorescent banding is sometimes common in different species (Ahmed et al. 2004, Alam et al. 2011). In these cases, the satellites or the chromosomes must be observed with orcein staining. In this study, the satellite of $T$. plantaginea could not be observed in orcein staining. The reason was not clear. Alam and Kondo (1995) reported some stain specific satellites and chromosomal segments in Drosera species after sequential staining with orcein, Giemsa C-banding, CMA and DAPI. They found that some satellites and segments were observed in some stain whether not in other. The satellite of T. plantaginea might have stain specificity, resulting in it being observed in DAPI but not in orcein and CMA. Therefore, the satellites of $T$. plantaginea were AT-rich and stain specific as well.

\section{Fluorescent banding}

Tacca plantaginea and T. chantrieri possessed many CMA positive bands. These bands were very thick and occupied much area at the terminal regions of either long arms or short arms of the respective chromosomes (Figs. $7,8)$. The percentage of CMA banded region was 62 
Table 1. Comparative orcein-, CMA- and DAPI-karyotype analysis of three species of Tacca J. R. \& G. Forst.

\begin{tabular}{|c|c|c|c|c|c|c|c|c|c|}
\hline Tacca species & $2 n$ & $\begin{array}{c}\text { Range of } \\
\text { chromosomal } \\
\text { length }(\mu \mathrm{m})\end{array}$ & $\begin{array}{l}\text { Total length of } \\
2 n \text { chromosome } \\
\text { complement }(\mu \mathrm{m})\end{array}$ & $\begin{array}{l}\text { Centromeric } \\
\text { formulae }\end{array}$ & $\begin{array}{c}\text { No. of } \\
\text { CMA-bands }\end{array}$ & $\begin{array}{l}\% \text { of } \\
\text { GC-rich } \\
\text { repeats }\end{array}$ & $\begin{array}{c}\text { No. of } \\
\text { DAPI-bands }\end{array}$ & $\begin{array}{l}\% \text { of } \\
\text { AT-rich } \\
\text { repeats }\end{array}$ & No. of satellites \\
\hline T. plantaginea & 28 & $0.92-1.88$ & 38.41 & $22 m+6 s m$ & 16 & 62.00 & 22 & 64.54 & 2 in DAPI \\
\hline T. chantrieri & 22 & $1.13-1.69$ & 28.43 & $18 m+4 s m$ & 14 & 46.52 & 12 & 47.56 & - \\
\hline T. integrifolia & 28 & $0.66-1.40$ & 31.30 & $28 \mathrm{~m}$ & 03 & 10.13 & 18 & 57.60 & 2 in Orcein and CMA \\
\hline
\end{tabular}

$\mathrm{m}=$ metacentric chromosomes, $\mathrm{sm}=$ submetacentric chromosome .

Table 2. Compilation of RAPD analysis in three species of Tacca J. R. \& G. Forst.

\begin{tabular}{|c|c|c|c|c|c|c|}
\hline \multirow{2}{*}{$\begin{array}{l}\text { Primer } \\
\text { codes }\end{array}$} & \multirow{2}{*}{$\begin{array}{c}\text { Size ranges } \\
\text { (bp) }\end{array}$} & \multicolumn{3}{|c|}{ Total bands } & \multirow{2}{*}{ Species specific unique bands (bp) } & \multirow{2}{*}{ Common bands (bp) } \\
\hline & & T. plantaginea & T. chantrieri & T. integrifolia & & \\
\hline OPA-6 & $300-500$ & 2 & 2 & - & - & $\begin{array}{l}2(300,500 \mathrm{bp}) \text { in } T \text {. plantaginea } \\
\quad \text { and } T \text {. chantrieri }\end{array}$ \\
\hline Primer-4 & $350-1000$ & 2 & 1 & 3 & $\begin{array}{l}1(600 \mathrm{bp}) \text { in } T . \text { plantaginea and } \\
\quad 2(1000,750 \mathrm{bp}) \text { in } T \text {. integrifolia }\end{array}$ & $350 \mathrm{bp}$ \\
\hline Primer-5 & $500-2000$ & 2 & - & 4 & $\begin{array}{l}1(2000 \mathrm{bp}) \text { in } T \text {. plantaginea and } \\
\quad 3(1400,800,500 \mathrm{bp}) \text { in } T \text {. integrifolia }\end{array}$ & $\begin{array}{l}1(750 \mathrm{bp}) \text { in } T \text {. plantaginea } \text { and } \\
\quad \text { T. integrifolia }\end{array}$ \\
\hline Primer-7 & $600-1400$ & 1 & 1 & 3 & $3(1400,900,600 \mathrm{bp})$ in T. integrifolia & $750 \mathrm{bp}$ \\
\hline Primer-8 & $350-450$ & - & 1 & 1 & $\begin{array}{l}1(450 \mathrm{bp}) \text { in } T . \text { chanterei and } \\
1(350 \mathrm{bp}) \text { in } T . \text { integrifolia }\end{array}$ & - \\
\hline Primer-11 & $600-750$ & - & - & 2 & $2(600,750 \mathrm{bp})$ in $T$. integrifolia & - \\
\hline
\end{tabular}

and 46 in $T$. plantaginea and T. chantrieri, respectively (Table 1). CMA bands represented GC-rich repeats (Schweizer 1976). It revealed that the GC-rich repeats were preferentially accumulated at the terminal ends rather than the other parts of the respective chromosomes. In contrast, only three chromosomes showed CMA bands in T. integrifolia with a minimum $10 \%$ GC-rich region (Fig. 9, Table 1). Therefore, the three species had distinct CMA banding patterns in the metaphase chromosomes.

A member of pair $\mathrm{V}$ in Tacca plantaginea, pair $\mathrm{X}$ of $T$. chantrieri and pair XIII of T. integrifolia fluoresced entirely with CMA (Figs. 16-18). Moreover, a member of pair XI of T. plantaginea, pair IX and X of T. chantrieri and pair X and XII of T. integrifolia fluoresced entirely with DAPI (Figs. 19-21). No band was found in their respective homologue members. The possible reason for this heteromorphicity was due to tandem duplication of GC- and AT-rich repeats on only a member of the respective pairs (Figs. 16-21). These types of heteromorphicity were also reported in different plants such as Alocasia fornicata (Afroz et al. 2013), Crinum spp. (Ahmed et al. 2004) and Xanthium strumarium L. (Alam et al. 2011). Therefore, like other species, preferential tandem duplication of GC-and AT-rich repeats happened in Tacca species.

In T. integrifolia, 18 DAPI bands were found. In this species, a member of pair I and both the members of pair VI had bands on two terminal ends (Figs. 12, 21). Except for a member of pair I in T. chantrieri (Fig. 20), no chromosome of the other two species had bands on two terminal ends (Figs. 19, 21). Therefore, these chromosomes could be used as marker chromosomes for the identification of the respective species. In $T$. chantrieri, a DAPI positive centromeric band was found in a member of pair II. No such band was found in its homologue member indicating the possible deletion of the AT-rich repeats from the centromere of the non-banded chromosomes (Figs. 19-21). Therefore, the three Tacca species have characteristic fluorescent karyotypes useful for authentic identification.

\section{RAPD analysis}

Initially, 10 different primers were used, of which six primer combinations showed clearer and reproducible bands. A few bands with different primers were common in three species indicating the sharing of similar fragments. On the other hand, no band was found in $T$. integrifolia with primer OPA-6, in T. chantrieri with Primer-5, in $T$. plantaginea with primer-8, and in $T$. plantaginea and T. chantrieri with primer 11, suggesting the lack of those loci in these species. Besides, each species had unique bands (Figs. 22-27, Table 2). A unique band is a band found in a species with a certain primer but absent in other species with the same primer. The unique bands were species specific and thus could be used as molecular markers. Therefore, each species had different RAPD fingerprinting which could be used for authentic identification and conservation.

\section{Taxonomic status of Tacca integrifolia}

Morphologically T. chantrieri and T. integrifolia look similar and are thus supposed to be very close, whereas T. plantaginea is morphologically different from these two species. However, cytogenetical and molecular data 


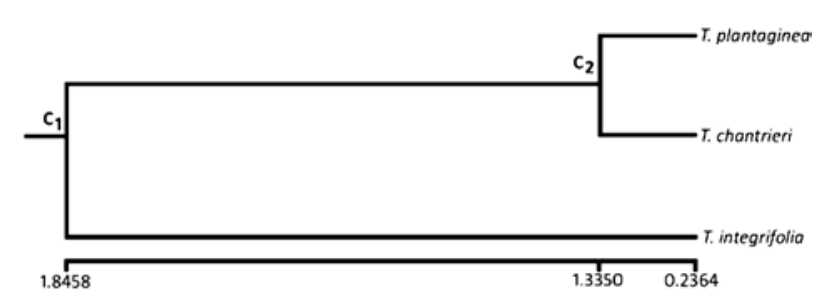

Fig. 28. UPGMA dendrogram based on Nei's (1972) genetic distance summarizing the data on differentiation between three species of Tacca by RAPD analysis.

were completely different, such as: i) $T$. integrifolia had only metacentric chromosomes whereas both metacentric and submetacentric types of chromosomes were found in the other two species, ii) T. integrifolia had a pair of GC-rich satellite; in contrast, no satellites were found in the other two species, iii) $T$. chantrieri had only three CMA bands with about $10 \%$ GC-rich repeats; on the other hand, many CMA bands with about $50 \%$ GC-rich repeats were found in the other two species, iv) DAPI bands on two terminal regions of chromosomes were found in $T$. integrifolia, which were absent in the other two species (except a chromosome of T. chantrieri), v) RAPD banding pattern showed much similarity between $T$. plantaginea and T. chantrieri, and vii) in the genetic dendrogram $T$. plantaginea and $T$. chantrieri have formed a cluster with minimum genetic distance $(0.2364)$ and $T$. integrifolia placed in separate cluster with highest genetic distance (1.8458) (Fig. 28). Therefore, T. integrifolia is distantly related from T. plantaginea and T. chantrieri.

\section{Acknowledgements}

This research was partly supported by a Grant from the Ministry of Science and Technology, People's Republic of Bangladesh (2014-15/BS-94/527).

\section{References}

Afroz, M., Sultana, S. S. and Alam, Sk. S. 2013. Karyotype and RAPD analysis of three morphological forms of Alocasia fornicata (Roxb.) Schott. Cytologia 78: 269-275.

Ahmed, L., Begum, R., Noor, S. S., Zaman, M. A. and Alam, Sk. S. 2004. Reversible fluorescent chromosome banding in three Crinum spp. (Amaryllidaceae). Cytologia 69: 69-74.

Ahmed, Z. U., Hossan, M. A., Begum, Z. N. T., Khondker, M., Kabir, S. M. H., Ahmad, M., Ahmed, A. T. A., Rahman, A. K. A. and Haque, E. U. 2008. Encyclopedia of Flora and Fauna of Bangladesh (Angiosperms Monocotyledons Orchidaceae-Zingiberaceae). Asiatic Society of Bangladesh, Dhaka. pp. 446-449.

Akter, S. and Alam, Sk. S. 2005. Differential fluorescent banding pattern in three varieties of Cicer arietinum L. (Fabaceae). Cytologia 70: 441-445.

Alam, Sk. S. and Begum, R. 2001. Differential staining of two forms of Datura metal L. Bangladesh J. Bot. 30: 37-41.

Alam, Sk. S. and Kondo, K. 1995. Differential staining with Orcein, Giemsa, CMA, and DAPI for comparative chromosome study of 12 species of Australian Drosera (Droseraceae). Am. J. Bot. 82: 1278-1286.
Alam, Sk. S., Sukur, M. B. and Zaman, M. Y. 2011. Karyotype analysis in two morphological forms of Xanthium strumarium L. Cytologia 76: 483-488.

Badr, S., Mustafa, A. E., Taher, W. and Sammour, R. H. 2009. Genetic variability in Lathyrus spp. as revealed by karyotype analysis. Cytologia 74: 101-111.

Baldwin, J. T. and Speese, B. M. 1951. Tacca involucrata: its chromosomes. Bull. Torrey Bot. Club 78: 70-72.

Bered, F., Terra, T. F., Spellmeier, M. and Neto, J. F. B. 2005. Genetic variation among and within sweet corn populations detected by RAPD and SSR markers. Crop Breed. Appl. Biotech. 5: 418-425.

Borokini, T. I. and Ayodele, A. E. 2012. Phytochemical screening of Tacca leontopetaloides (L.) Kuntze collected from four geographical locations in Nigeria. Int. J. Mod. Bot. 2: 97-102.

Chen, Z. L., Wang, B. D. and Chen, M. Q. 1987. Steroidal bitter principles from Tacca plantaginea structures of Taccalonolide A and B. Tetrahedron Lett. 28: 1673-1675.

Doyle, J. J. 1987. A rapid DNA isolation procedure for small quantities of fresh leaf tissues. Phytochem. Bull. 19: 11-15.

Huang, Y., Liu, J. K., Mühlbauer, A. and Henkel, T. 2002. Three novel Taccalonolides from the tropical plant Tacca subflaellata. Helv. Chim. Acta 85: 2553-2558.

Islam, M. and Alam, Sk. S. 2011. Karyotype characterization with fluorescent banding in one released and two wild germplasms of Hibiscus cannabinus L. Cytologia 76: 223-227.

Jessy, N. S., Begum, R., Khatun, M. and Alam, Sk. S. 2005. Differential fluorescent chromosome banding of four species in Haworthia duval (Aloaceae). Cytologia 70: 435-440.

Khatun, M. and Alam, Sk. S. 2010. Confirmation of species status of Corchorus trilocularis and C. pseudo-olitorius by differential chromosome banding and isozyme assay. Cytologia 75: 83-88.

Khatun, M., Sultana, S. S., Ara, H., Islam, M. N. and Alam, Sk. S. 2011. Differential chromosome banding and isozyme assay of three Corchorus spp. Cytologia 76: 27-32.

Kondo, T. and Hizume, M. 1982. Banding for the chromosomes of Cryptomeria japonica D. Don. J. Jpn. For. Soc. 64: 356-358.

Kumar, V. and Subramaniam, B. 1987. Chromosome Atlas of Flowering Plants of the Indian Subcontinent: Dicotyledons. Botanical Survey of India, Calcutta. p. 464.

Nei, M. 1972. Genetic distance between populations. Am. Nat. 106: 283-292.

Prain, D. 1963. Bengal Plants. India Botanical Survey, Calcutta.

Schweizer, D. 1976. Reverse fluorescent chromosome banding with chromomycin and DAPI. Chromosoma 58: 307-324.

Sharma, A. K. and Sarkar, A. K. 1968. Chromosome number reports of plants. Res. Bull. Univ. Calcutta 2: 38-48.

Shwe, H. H., Aye, M., Sein, M. M., Htay, K. T., Kreitmeier, P., Gertsch, J., Reiser, O. and Heilmann, J. 2010. Cytotoxic steroidal saponins from the rhizomes of Tacca integrifolia. Chem. Biodivers. 7: 610-622.

Stebbins, G. L. 1971. Chromosomal Evolution in Higher Plants. Edward Arnold, London. p. 208.

Sultana, S. S. and Alam, Sk. S. 2007. Differential fluorescent chromosome banding of Solanum nigrum L. and Solanum villosum L. from Bangladesh. Cytologia 72: 213-219.

Sultana, S. S., Ara, H. and Alam, Sk. S. 2011. Karyotype analysis with orcein and CMA in two species of Alocasia (Schot T) G. Don (Araceae). Bangladesh J. Bot. 40: 53-56.

Ting, C. C. and Larsen, K. 2000. Taccaceae. In: Flora of China 24: 274-275.

van Steenis, C. G. G. J. 1975. Flora Malesiana. Sijthoff \& Noordhoff International Publishers, Alphen aan den Rijn. pp. 755-876.

Williams, J. G., Kubelik, A. R., Livak, K. J., Rafalski, J. A. and Tingey, S. V. 1990. DNA polymorphisms amplified by arbitrary primers are useful as genetic markers. Nucleic Acids Res. 18: $6531-6535$. 
Yokosuka, A., Mimaki, Y., Sakagami, H. and Sashida, Y. 2002. New diarylheptanoids and diarylheptanoid glucosides from the rhizomes of Tacca chantrieri and their cytotoxic activity. J. Nat. Prod. 65: 283-289.

Yokosuka, A., Mimaki, Y., Sakuma, C. and Sashida, Y. 2005. New glycosides of the campesterol derivative from the rhizomes of Tacca chantrieri. Steroids 70: 257-265.

Yokosuka, A., Mimaki, Y. and Sashida, Y. 2003. Chantriolides A and B, two new withanolide glucosides from the rhizomes of Tacca chantrieri. J. Nat. Prod. 66: 876-878.

Zhang, L., Li, H. T., Gao, L. M., Yang, J. B., Li, D. Z., Cannon, C. H., Chen, J. and Li, Q. J. 2011. Phylogeny and evolution of bracts and bracteoles in Tacca (Dioscoreaceae). J. Integr. Plant Biol. 53: 901-911.

Zhou, J., Chen, C., Liu, R. and Yang, C. 1983. Studies on the chemical constituents of Tacca chanteraeri Andre. Zhiwu Xuebao 25: $568-573$. 